\title{
Архитектура Адмиралтейства в Санкт-Петербурге как основная часть девелоперского проекта рефункционирования судостроительной верфи
}

\author{
Л.П.Лавров, СПБГАСУ, Санкт-Петербург \\ Ф.В.Перов, СПБГАСУ, Санкт-Петербург \\ А.Ф.Еремеева, СПБГАСУ, Санкт-Петербург
}

Отмечается несостоятельность представления о СанктПетербурге как о городе, «рождённом из пробирки», вся застройка которого выполнялась по заранее задуманному плану. Ландшафты исторического центра города формировались в процессе изменения градостроительной ситуации на протяжении двух столетий. Одним из примеров является эволюция комплекса Адмиралтейства. Изначально построенное в качестве верфи, здание подверглось перестройке и приспособлению под новые цели в XVIII-XIX веках. Выявлена связь произведённых изменений с общим процессом развития города, в частности, - с совершенствованием застройки центра и расширением судостроительного производства. $\mathrm{K}$ началу царствования Александра I Адмиралтейская верфь была затухающим производством, а для разрастающихся учреждений Морского ведомства требовались дополнительные помещения в центре города. Отмечено, что выполненная А.Д. Захаровым реконструкция была обусловлена финансовым лимитом, личными указаниями Александра I и опиралась на опыт, приобретённый зодчим при разработке проекта комплекса Академии наук на Васильевском острове. Обращается внимание, что параллельно с реконструкцией корпусов Адмиралтейства проводились преобразования примыкающих к нему участков территории. Подчёркнуто, что преобразования, произведённые вокруг комплекса Адмиралтейства во второй половине XIX века, «затушевали» в городском ландшафте уникальный памятник русского ампира - главный фасад Адмиралтейства. Сегодня главный фасад Адмиралтейства плотно прикрыт густой зеленью Александровского сада, разбитого в 1870-е годы. Высказаны предложения по формированию партерного сада вместо дикой массы стихийно разросшихся деревьев, созданию гармоничной композиции регулярного озеленения и величественной архитектуры.

Ключевые слова: архитектура и градостроительство СанктПетербурга, реконструкция, судостроительный комплекс, Адмиралтейство, А.Д. Захаров.

Architecture of the Admiralty in St. Petersburg as the Main Part of the Shipyard Refunctioning Developer Project

L.P.Lavrov, SPSUACE, Saint-Petersburg

F.V.Perov, SPSUACE, Saint-Petersburg

A.F.Eremeeva, SPSUACE, Saint-Petersburg

The failure of the idea of St. Petersburg as a city, "born from a test tube", all the construction of which was carried out according to a pre-planned plan is noted in the article. The landscapes of the historic center of the city were formed in the process of changing the urban situation during the two centuries. The evolution of the Admiralty complex is one of the examples. Originally built as a shipyard, the building was rebuilt and adapted for new purposes in the XVIII-XIX centuries. The connection of the changes with the overall process of the city development, in particular, with the improvement of the center's development and expansion of shipbuilding production is revealed. By the beginning of the reign of Alexander I, the Admiralty shipyard was a decaying production, and for the growing institutions of the Maritime Department, additional premises in the city center were required. It is noted that the reconstruction, performed by A.D. Zakharov, happened due to the financial limit, the personal instructions of Alexander I and were based on the experience gained by the architect in the development of the project complex of the Academy of Sciences on Vasilevsky island. The attention is drawn on the fact that in parallel with the reconstruction of the buildings of the Admiralty complex the transformation of adjacent areas of the territory was carried out. It is emphasized that the transformations, made around the Admiralty complex in the second half of the XIX century, "obscured" a unique work of Russian empire - the main facade of the Admiralty - in the urban landscape. Today, the main facade of the Admiralty is tightly covered with dense greenery of the Alexander garden, which waslaid out in the 1870s. The proposals on the formation of a parterre garden instead of wild mass of spontaneously overgrown trees in order to create a harmonious composition of regularlandscaping and majestic architecture are given.

Keywords: architecture and urban planning of St. Petersburg, reconstruction, shipbuilding, Admiralty, A. D. Zakharov.

При обсуждении выдающихся архитектурно-градостроительных достоинств исторического ядра Санкт-Петербурга лишь иногда затрагиваются те детерминанты его развития, которые имеют чисто утилитарный характер и типичны для любого растущего города - ограниченность ресурсов, изменение возможностей и запросов, личная заинтересованность лиц, принимающих решения. В числе причин, определивших композиционно-эстетическое совершенство городского центра, обычно называют уникальные особенности проектно-строительного комплекса бывшей столицы - постоянное целенаправленное управление, привлечение выдающихся 
зодчих, личное внимание царствующих особ. Ориентация на историко-искусствоведческие аспекты, характерная для профессиональных кругов, способствовала распространению устойчивых мифов. Они затрагивают и Адмиралтейство, которое относится к числу самых известных архитектурных памятников Санкт-Петербурга.

Наиболее распространено представление о том, что эта постройка появилась в начале XIX века. Эту версию излагает установленная на главном фасаде мраморная доска: «Зданіе Главнаго Адмиралтейства построено въ 1811 году по проекту русскаго зодчаго Андріана Захарова». Учебное пособие для школьников пятых-девятых классов с расчётом на детскую доверчивость сообщает: «Здание Адмиралтейства в Петербурге построено замечательным русским архитектором А.Д. Захаровым. Захаров задумал создать грандиозное здание протяжённостью почти в четыреста метров» [1]. Появляются и парадоксальные заявления. В Краткой биографической энциклопедии сообщают о «перестройке прежней адмиралтейской крепости в нынешнее здание Адмиралтейства» [2]. Уверяют, что «...старые корпуса были разобраны и построены новые» [3]. Не столь радикальна версия популярного издания: Захаров «решил сохранить конфигурацию старого здания, увеличив при этом его главный фасад до 407 метров» [4].

Профессиональные издания чаще всего концентрируют внимание на композиционно-эстетических качествах объекта, на элементах декора. Условия, определившие ход реконструкции комплекса и обеспечившие исключительно позитивный её результат, если и затрагиваются, то лишь фрагментарно. Между тем, положительный опыт петербургского «девелопмента» в начале XIX века может представлять не только познавательный интерес, но получить отклик и в современной практике.

Реконструкция Адмиралтейства показательна как пример реализации проекта со стопроцентным государственным участием. Верфь была крупнейшим казённым предприятием города, находилась в самом центре столицы. Не удивительно, что лицом, принимавшим ключевые решения в этом проекте, был лично император Александр I. Определял условия реконструкции и контролировал её ход заинтересованный министр морских сил адмирал П.В. Чичагов. Разработка проекта была возложена на «главных Адмиралтейств архитектора» А.Д. Захарова.

\section{Предыстория}

К началу XIX века судостроительный комплекс в СанктПетербурге функционировал полное столетие. Его центральным элементом было Адмиралтейство, сохранявшее те основные планировочные параметры, которые были заданы 16 (5) ноября 1704 года основателем верфи Петром I. В походном журнале императора записано: «Заложили Адмиралтейский дом и веселились в остерии, длина 200 сажен, ширина 10 сажен» [5] (в современных мерах - 425×213 метров). Установленные габариты верфи были близки размерам жилых кварталов, которые впоследствии стали подниматься на Васи- льевском острове - 210×66 сажен (447,3×140,6 м) [6], но место для неё отвели вне селитебной зоны - на болотистом островке между Невой и Мойкой, на относительно сухом освоенном участке, где находилось сельцо Гагуево. Проектный эскиз утвердил лично Петр, и здание верфи вскоре было построено «покоем» (в форме буквы «П»): одноэтажные мазанковые производственные корпуса расположили по периметру открытого к Неве «построечного двора», на котором вели сборку судов. В 1711 году голландский мастер Харман ван Болос поднял над Адмиралтейством на высоту 72-х метров шпиль с корабликом-флюгером - первое в Петербурге сооружение подобной высоты (шпиль Петропавловского собора достиг отметки 112 метров в 1720 году) (рис. 1).

Здание верфи стало центром обширной градостроительной структуры. Вокруг производственной территории возвели обширные укрепления Адмиралтейской крепости (рвы, земляные валы, свободные от застройки луга гласисов). Чуть в стороне расположилась рабочая слобода судостроителей. Вскоре пришлось задуматься о расширении производства, поэтому в Адмиралтействе оставили судосборочные стапеля, а для заготовительных цехов и складов выделили дополнительную площадку. Она протянулась на запад параллельно руслу Невы примерно на два километра и включила острова Новая Голландия и Галерный. Технологические связи комплекса обеспечивала система каналов. Главный из них (Адмиралтейский) был прокопан уже в 1717 году (рис. 2).

В 1727 году началась первая реконструкция комплекса Адмиралтейства: по проекту И.К. Коробова взамен мазанковых петровских корпусов возвели кирпичные производственные здания, что оказалось весьма предусмотрительно, так как позволило защитить производство от разрушительных пожаров, случившихся в Петербурге в 1736 и 1737 годах. Тогда сгорели 350 из 520 находившихся на Адмиралтейском острове жилых

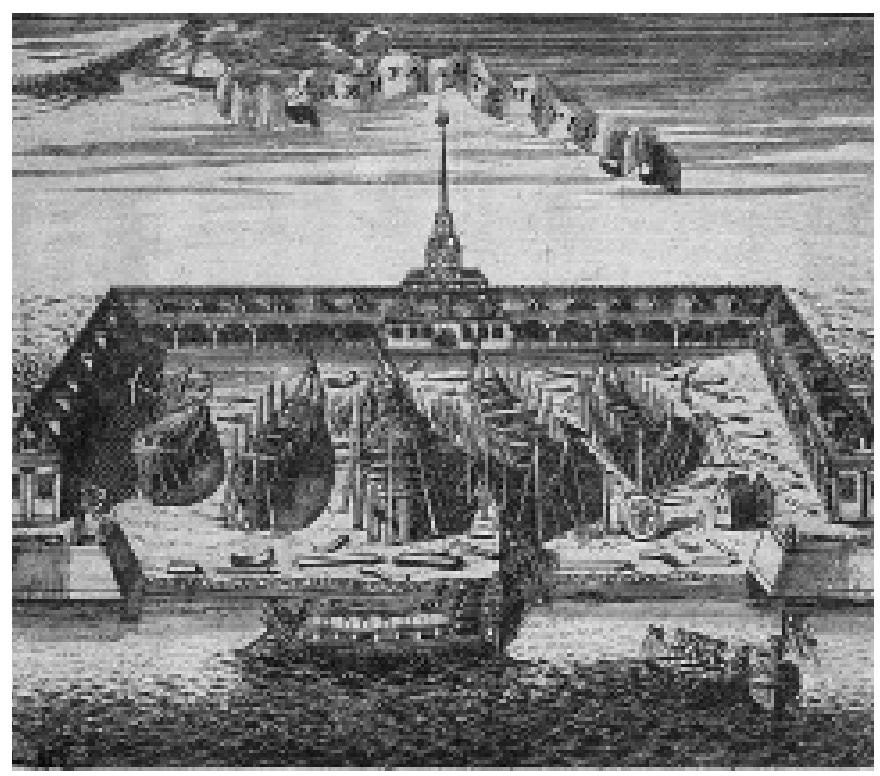

Рис. 1. Адмиралтейство в петровскую эпоху [7] 
домов (в большинстве своём - деревянных). В 1734-1737 годах неоднократно перестраивалась центральная башня со шпилем, имеющая доминантное значение, что можно связать с выполнявшейся в эти годы И.К. Коробовым проработкой центральной части плана города.

В 1738 году в проекте восстановления города «Комиссия о Санкт-Петербургском строении» отвела Адмиралтейству исключительную градоформирующую роль: его шпиль стал композиционным центром трёхлучевой системы главных улиц - «Адмиралтейского трезубца» (Невский и Вознесенский проспекты, Гороховая улица). К середине XVIII века верфь оказалась в самом центре Петербурга, а её внешний вид никак не соответствовал складывавшемуся презентабельному облику застройки (рис. 3). Верфь с прилегающими укреплениями Адмиралтейской крепости занимала огромную территорию и представляла собой «безобразную длинную фабрику, окружённую подъёмными мостами, рвами глубокими, но нечистыми, заваленными досками и брёвнами» [9].

В 1762 году в только что возведённом Зимнем дворце поселилась Екатерина II. Сложившееся соседство верфи и императорской резиденции породило новые конфликты, поскольку царице мешал шум судостроительного производства и запахи смолы, которые несли с собой западные ветры. В 1782 году на верфях случился страшный пожар, чуть было не перекинувшийся на Зимний дворец. Напуганная Екатерина II задумалась о переносе судостроительного производства в Кронштадт, подальше от дворца [5]. Реализация идеи требовала времени и очень больших денег (чиновники Адмиралтейств-коллегии представили смету на 9000000 рублей), поэтому дело отложили в «долгий ящик».



Рис. 2. Крепость Адмиралтейская и головная часть комплекса верфи. 1736 год [8]

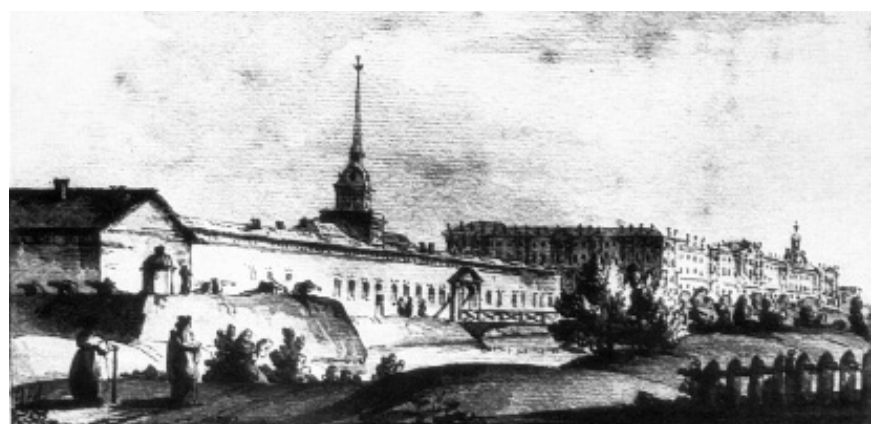

Рис. 3. Комплекс Адмиралтейства и Зимний дворец в 1790-е годы. Зарисовка Д. Кваренги [10]
Павла I, царствовавшего с 1796 по 1801 год, неудобства соседства с Адмиралтейством не волновали, поскольку он не собирался долго жить в Зимнем дворце (для него спешно строили новую укреплённую резиденцию - Михайловский замок). Главными для него были военные заботы: международные обстоятельства требовали, чтобы Балтийская эскадра получала суда нового класса и в бо́льшем количестве. Ресурсы петровского Адмиралтейства были на исходе, поэтому в 1799 году по указу Павла I началось расширение Галерной верфи, которая получила название «Новое Адмиралтейство» [11]. Для Павла I Адмиралтейская верфь в центре города была затухающим производством, но он считал важным повысить респектабельность оказавшейся в центре Адмиралтейской крепости, поскольку, как пишет современник, по его мнению, «каналы, заваленные лесами, изрытый гласис и другие обветшалости уже требовали очищения и поправок» [12].

У Александра I на этот счёт было совсем другое мнение. Обновление облика российской столицы молодой император воспринимал как важную личную цель. Уже в первый год царствования он заложил Казанский собор, затем затеял украшение в новом стиле Большого Каменного театра, реконструкцию Горного института и недостроенной Биржи на Стрелке Васильевского острова. В 1805 году дошла очередь и до Адмиралтейства. Современник писал о замеченной им «дикой и печальной нестройности Адмиралтейства, которое ещё притом, от высоты окружающего его земляного вала, казалось низким и мрачным: глаза утомлялись от таковой несогласной картины и могли приятно останавливаться только на одном золотистом шпице средней башни. Необходимость перестроить сие важное здание не укрылось от попечительного внимания государя императора!» [12].

\section{Реконструкция Адмиралтейства в начале XIX века}

Александр считал необходимым провести реконструкцию всего комплекса Адмиралтейства - укрепления были не нужны, а занимали огромную территорию, столетние верфи к тому же уже теряли прежнее значение (судостроительное производство перемещалось в Новое Адмиралтейство), а для разрастающихся учреждений Морского ведомства требовались дополнительные помещения в центре города. В 1805 году в должности «Главных Адмиралтейств Архитектора» утвердили А.Д. Захарова и поручили подготовить отвечающий такой ситуации проект [7].

Можно предположить, что своеобразной рекомендацией для служебного продвижения А.Д. Захарова послужила предложенная концепция реконструкции комплекса Академии наук на Васильевском острове, с которой император ознакомился 12 июня 1804 года, когда лично апробировал и утверждал проект «Биржевого местоположения» [13]. В составе проектной документации были заинтересовавшие Александра I эскизы А.Д. Захарова. Исследователи архитектуры до сих пор не уделили этой работе зодчего такого 
же пристального внимания, как император. Он увидел на этих архитектурных чертежах не только выразительную демонстрацию любимого им стиля ампир, но и то направление, по которому следовало действовать при предполагавшейся реконструкции Адмиралтейства.

Проект комплекса Академии наук не был реализован, но предполагавшийся архитектурный облик этого сооружения зафиксировал художник Б. Патерсен в литографии «Вид на Стрелку Васильевского острова со стороны Дворцовой набережной». Сравнение объекта, задуманного А.Д. Захаровым в 1804 году, с позже реализованным им Адмиралтейством удивляет сходством ключевых композиционно-эстетических признаков:

- основу композиции составляют существующие строения (на Васильевском острове - здание Кунсткамеры и построенный Кваренги корпус Академии наук);

- сопоставимость определяющих габаритов (протяжённость главного фасада Адмиралтейства - около четырёхсот метров, а намечавшегося комплекса на Васильевском - более трёхсот);

- расчёт на восприятие с дальних точек, продиктованный градостроительной ситуацией;

- единство стилистики (русский ампир) и идентичность композиционной базы (симметричное трёхчастное членение с высотной доминантой по центру);

- использование центрального элемента для выявления истории здания (башня комплекса на Васильевском острове сохранённым барочным обликом напоминает о Кунсткамере, а шпиль Адмиралтейства - о произведении Коробова).

На рисунке 4 заметно, что в облике Адмиралтейства А.Д. Захаров существенно обогатил композиционную схему комплекса, добился большей его целостности, но при этом усложнил пластику ризалитов.

Опыт, полученный при разработке проекта комплекса Академии наук, позволил А.Д. Захарову в кратчайшие сроки дать предложения по реконструкции Адмиралтейства. Основа его концепции отвечала на условия жёсткой экономии и предполагала максимальное сохранение существовавших конструкций. Суть идеи архитектор изложил в записке, поданной адмиралу П.В. Чичагову: «Составляя сей проект, первым правилом поставлял соблюсти сколь возможно выгоды казны, что и побудило меня старые стены и фундаменты не расстраивать ломкой, почему и прибавлено голых стен весьма мало...» [12]. Эту концепцию разъясняет схема, выполненная на основе первоначального эскиза (рис. 5): красным цветом выделены существовавшие корпуса, черным - добавленные А. Захаровым новые элементы. Видно, что для украшения фасадов он решил ограничиться пристройкой небольших по протяженности декоративных элементов. Самый больший объём работ приходится на выходящие к Неве части комплекса, где торцевые части параллельных корпусов объединяются новыми павильонами.
Уже в 1806 году проект был утверждён, начались строительные работы. Основные преобразования существовавшей постройки отражали единство функциональных, конструктивных и эстетических установок:

- оконные проёмы в стенах между ризалитами через один замуровали, что позволило не только укрупнить масштаб фасада, но и увеличить несущую способность конструкции, обеспечить возможность надстройки,

- с расчётом на возможности существовавших фундаментов высоту стен увеличили с 9,92 м до 16,51 м, что позволило разместить дополнительный этаж и придать фасаду желаемые пропорции.

Применённые для обогащения фасадов декоративные средства находились в русле петербургского «русского ампира». Использовался набор форм, характерных для архитектуры этого периода: определяющими были сдержанность и лаконичность. «Суровый, стройный вид» постройки подчеркивался гладкими штукатурными колоннами возведённых портиков с дорическими капителями. Исключение было допущено только для центральной башни - её колоннаду обогатили ионические капители. Композиционные при-

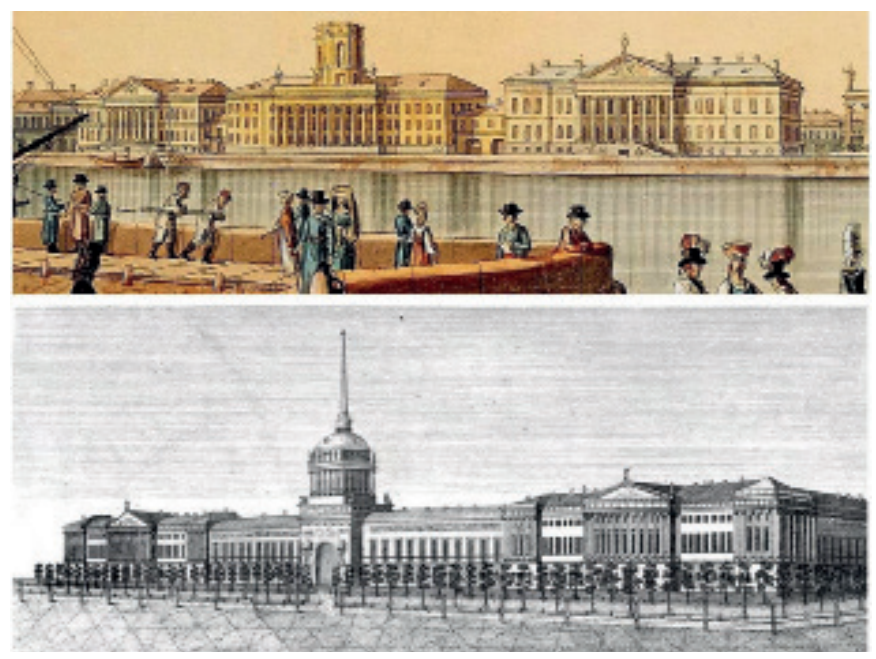

Рис. 4. Вверху - комплекс Академии наук на Васильевском острове -фрагмент раскрашенной гравюры Б. Патерсена. 1807 год [14]. Внизу-вид Адмиралтейства в 1820-е годы [15]

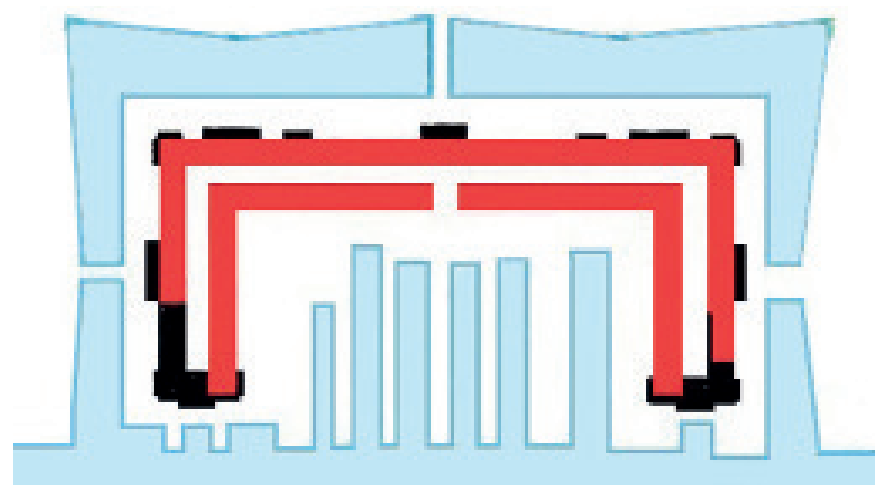

Рис. 5. Эскизная схема реконструкции Адмиралтейства (с использованием [16 ]) 
ёмы предложенного А.Д. Захаровым обогащения фасадов полностью соответствовали канонам «александровского классицизма». Исключительный талант зодчего проявился в умении привести габариты существовавшего фасада в соответствие с градостроительной ситуацией и соединить на нём узнаваемые элементы в уникальную художественную систему.

Обновление комплекса начали с той части Адмиралтейства, которая прилегала к Зимнему дворцу. В 1808 году, когда реконструированный восточный корпус подвели под крышу, Александр I заметил, что он «отнимает вид из собственных его комнат на Галерную гавань и устье Невы». Пришлось разбирать примыкающую к Неве часть постройки (в том числе новый Невский павильон) перерабатывать весь проект [17].

Работы затянулись. В 1811 году, когда переустройство восточной части Адмиралтейства уже завершалось, скончался А.Д. Захаров, что не могло не сказаться на ходе работ. Затем повлияли финансовые ограничения в годы войны с Наполеоном. Наследниками А.Д. Захарова на стройплощадке стали его помощники - сначала А.Г. Бежанов, затем Д.И.

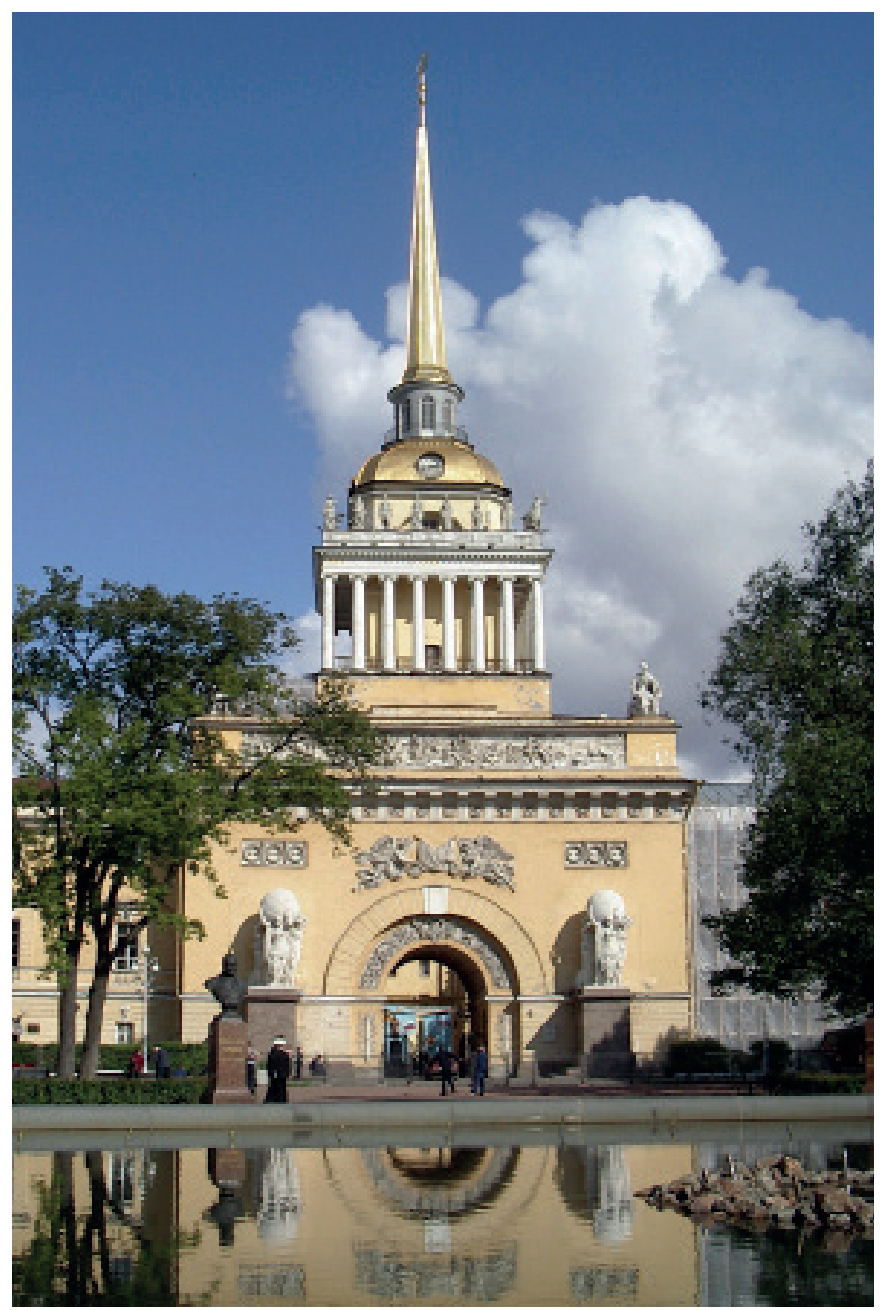

Рис. 6. Центральная башня Адмиралтейства. Фото 2010-х годов
Калашников и И.Г. Гомзин (с 1816 года). Проект был официально завершён в 1823 году, но приспособление Адмиралтейства под новые цели продолжалось и позже. Сейчас мало кто вспоминает об исчезновении огромных лепных фризов на фасадах, которое произошло в 1830-е годы, когда архитектор Э. К. Аннерт разместил на этих местах квадратные окна для освещения комнат третьего этажа (некотрое представление об этих исчезнувших деталях даёт рисунок 4). Результат работы по достоинству был оценён современниками. В книге «Достопамятности Санкт-Петербурга и его окрестностей» П. П. Свиньин (издатель «0течественных записок») отмечал успешное сочетание прикладных и эстетических качеств Адмиралтейства: «Сие важное и полезное здание принадлежит ныне к числу главных украшений столицы и весьма справедливо может быть названо исполинским свидетелем новейших успехов русского зодчества» [12].

\section{Судьба Адмиралтейской крепости}

Параллельно с реконструкцией строительных корпусов Адмиралтейства проводились преобразования примыкающих к нему участков территории. К этой работе привлекались различные городские и военные структуры. В связи с сокращеним роли Адмиралтейства в петербургском судостроительном комплексе уже к 1810-му году поспешили засыпать пересекавшую Исаакиевскую площадь часть Адмиралтейского канала. Внутренний канал между производственными корпусами, который ранее был необходим верфи по технологическим соображениям, осушили в 1817 году.

В 1816 году обсуждалась судьба каналов Адмиралтейской крепости. Проект Захарова предполагал, что им следует придать представительный облик по образцу набережных Мойки - облицевать берега гранитом, установить чугунную ограду, перекинуть каменные мосты. Можно предполагать, что и здесь зодчий учитывал опыт работы над комплексом Академии наук, дополнительную респектабельность которому должны были придавать каменная набережная перед фасадом и зеркальное отражение в водной глади. Решающими стали соображения экономии, и в 1817-1818 годах каналы были засыпаны [18]. 0 потенциале утерянной возможности сейчас можно судить лишь фрагментарно там, где центральный павильон отражается в воде бассейна, установленного в 1879 году (рис. 6).

Благодаря проведённой реконструкции комплекса Адмиралтейства к началу 1820 годов центр Петербурга преобразился самым радикальным образом. На месте бывшего гласиса вокруг здания Адмиралтейства открылась система огромных площадей (Исаакиевская и Петровская с западной стороны, Адмиралтейская - с южной, Дворцовая площадь и Разводная площадка - с восточной). Они находились в тесном взаимодействии между собой и с «главной площадью» Санкт-Петербурга - величественной акваторией Невы. 
Своеобразным напоминанием об исчезнувшей системе укреплений стал бульвар, в то время пользовавшийся большой популярностью «в свете». Центральная аллея, состоявшая из трёх прямолинейных участков общей протяженностью около 1200 метров, тесно охватывала корпуса Адмиралтейства. По бокам дорожка аллеи была обсажена рядами стриженых деревьев. Там, где аллея в двух местах выходила к берегам Невы (восточнее и западнее комплекса Адмиралтейства), в 1824 году по проекту К.И. Росси были сооружены монументальные гранитные спуски к воде. Они закрепляли связь открытых площадей с центром всей этой системы - акваторией Невы. Впечатление, которое производил бульвар на современников, описывает К.П. Батюшков, отмечая основные архитектурные достопримечательности, открывавшиеся во время прогулок перед взорами горожан: «Адмиралтейство, перестроенное Захаровым, превратилось в прекрасное здание и составляет теперь украшение города. <....> Вокруг сего здания расположен сей прекрасный бульвар, обсаженный липами, которые все принялись и защищают от солнечных лучей. Прелестное, единственное гульбище, с которого можно видеть всё, что Петербург имеет величественного и прекрасного: Неву, Зимний дворец, великолепные дома Дворцовой площади, образующей полукружие, Невский проспект, Исакиевскую площадь, Конногвардейский манеж, который напоминает Пантеон, прелестное строение г. Гваренги, Сенат, монумент Петра I и снова Неву с ее набережными!» [9].

Впрочем, сейчас практически невозможно разглядеть монументальный главный фасад Адмиралтейства - он плотно прикрыт густой зеленью Александровского сада, разбитого на месте Адмиралтейской площади в 1870-е годы. Преобразования этого периода можно считать следующей фазой реконструкции территории Адмиралтейства. К ней шли с 1844 года - тогда судостроение в центре города полностью прекратилось, и выходящая к Неве обширная территория «построечного двора» опустела. В 1870 -е годы её передали под застройку, а берега решили благоустроить. Тогда поняли, сколь дальновидным было вмешательство Александра I в проект реконструкциии: установленный по его повелению большой зазор между Невским павильоном и береговой линией оказался достаточен не только для прокладки необходимого проезда, но и разбивки зелёного бульвара (рис. 7).

Сейчас выходящий к Неве фасадный фронт составлен из солидных представительных зданий, представляющих варианты «европейского историзма», архитектурное решение каждого из которых не рассчитано на взаимодействие с соседними строениями. Тем не менее пространственную связь поддерживают единые красная линия и отметка венчающего карниза. Наиболее диссонирующий элемент - сгоревший в 1917 году «Панаевский театр» был в 1958 году заменён корпусом нейтральной архитектуры, примыкающую к Невскому павильону часть которого заглубили внутрь квартала (арх. Л.Н. Линдрот).

Современное Адмиралтейство представляет собой многофункциональный квартал в самом центре исторического Петербурга и содержит в себе характерные признаки города: господствующая в силуэте горизонтальность контрастирует с одинокой острой вертикалью, сдержанность и однородность основной архитектурной ткани - с яркостью и неповторимостью композиционно-смыслового ядра - золочёного шпиля с корабликом наверху. Его главный фасад можно уподобить ансамблю ампирной застройки, составленной из

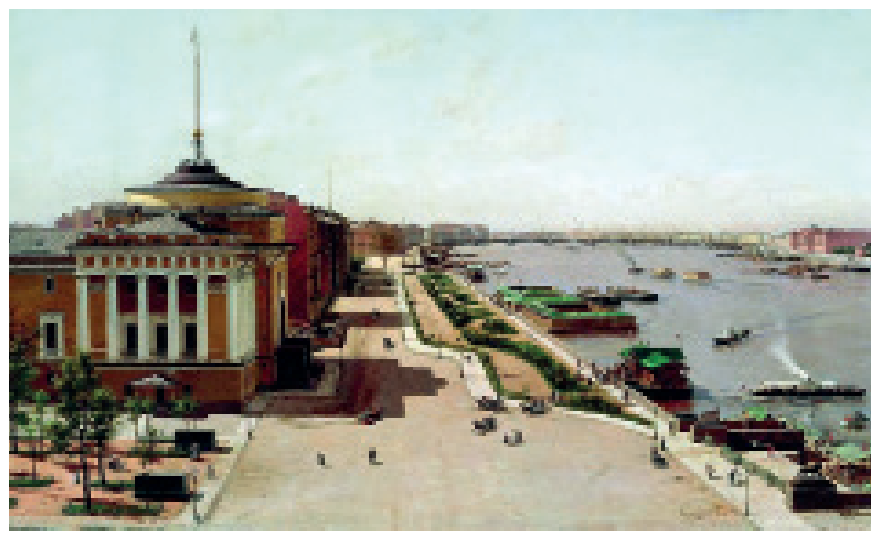

Рис. 7. Беггров А.К. Вид на Неву и Адмиралтейскую набережную. 1881 год [19]

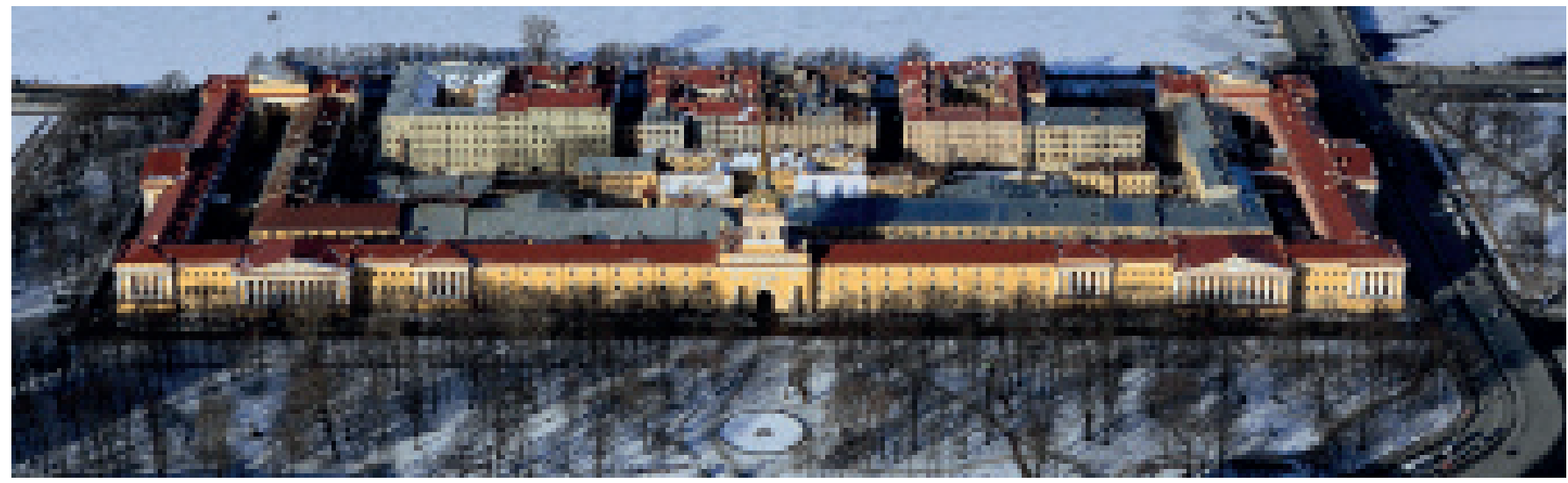

Pис. 8. Вид с птичьего полёта на квартал Адмиралтейства сюжной стороны [20] 
пяти зданий, объединённых единством композиционного построения и стилевой характеристики. К сожалению, это грандиозное и уникальное произведение русского ампира ныне плотно прикрыто зеленью парка и в полном объёме его можно увидеть с большой высоты зимой, когда опадают листья (рис. 8).

\section{Заключение}

В статье показана ошибочность представления о СанктПетербурге, как о «заранее спланированном городе», о «городе из реторты»[21]. Рисунок 9 демонстрирует, что прославленные ландшафты его исторического центра формировались в процессе изменения градостроительной ситуации на протяжении двух столетий. Как свидетельствуют материалы статьи, направление архитектурно-градостроительной эволюции базировалось на меняющихся канонах эстетических предпочтений и расчётливых функциональных требованиях, но учитывало и личные соображения лиц, принимающих решения. Эти же детерминанты определили содержание реконструкции Адмиралтейства, осуществленной по проекту А.Д. Захарова. Несомненного успеха гениальный зодчий добился минимальными средствами, полностью сохранив существующие конструкции зданий и лишь дополнив их выразительными архитектурными элементами. Остается сожалеть, что наиболее выразительная составляющая комплекса и широко известная по многочисленным публикациям - его главный фасад - недоступна для обозрения из-за разросшейся зелени сада, разбитого на площади в 1870-е годы. На эту утрату обратили внимание авторитетные искусствоведы, которым довелось ещё видеть здание во всей красе:

- «Весь фасад Адмиралтейства закрыт рощами плохо спланированного Александровского сада» [22];

- «К сожалению, вся площадь перед главным фасадом Адмиралтейства, еще более усиливавшая то впечатление, на которое рассчитывал автор, в настоящее время засажена садом. Площадь исчезла, красота и внушительность здания проиграны» (стр. 504) [23];

С конца XIX века самые авторитетные зодчие настаивают на освобождении его от подступившего массива высоко- ствольной зелени, считая сложившуюся ситуацию «градостроительным варварством»: «В сто первый раз хочется выказать уверенность, что ансамбль Адмиралтейства и детали этой, редчайшей в мире, архитектурной композиции будут в недалёком будущем восстановлены» [24].

Правила охраны территорий центра Санкт-Петербурга как объекта Всемирного наследия не исключают мер, направленных на регенерацию исторической среды [25]. Самые решительные действия по этому направлению были предприняты еще в 1890 году: по личному указанию императора Александра III были вырублены деревья в той части Александровского сада, где зелень закрывала вид на Медного всадника [26]. В наше время такую радикальную технологию одобряют немногое, но методики современной ландшафтной архитектуры и садовопаркового искусства позволяют надеяться, что последующая реконструкция сформирует в центре Петербурга дворцово-парковый ансамбль, соответствующий значимости места, а фасад Адмиралтейства станет доступен для обозрения.

Авторы статьи полагают, что следует преобразовать Александровский сад и вместо дикой массы стихийно разросшихся деревьев сформировать партерный сад с аккуратно подстриженными кронами, заменить часть деревьев на кустарники. В составе партерного сада вдоль фасадов Адмиралтейства мог бы быть возрождён бульвар, существовавший здесь ранее, в первой трети XIX века. Регулярное озеленение во взаимодействии с величественной архитектурой производило большой эффект на современников, что запечатлено в работах пейзажистов И. Барта, К.П. Беггрова, И.А. Иванова, И.Г. де Майра, А.Е. Мартынова, Ф. Перро, Г.Г. Чернецова: сначала прозрачные стриженые деревца растворяются на фоне строения, а потом их аккуратные округлые кроны ожерельем вытягиваются вдоль стен, затем соединившаяся в плотную массу зелень начинает зашторивать стены постройки. Данные меры позволили бы раскрыть главный фасад Адмиралтейства, сохранив при этом озеленённое пространство в центре Санкт-Петербурга.

Наше наследство - не только огромная ценность, но и обременение. Доставшийся нам исторический центр города требует расчистки от случайных наслоений, наносящих его гармоничным ландшафтам огромный ущерб.

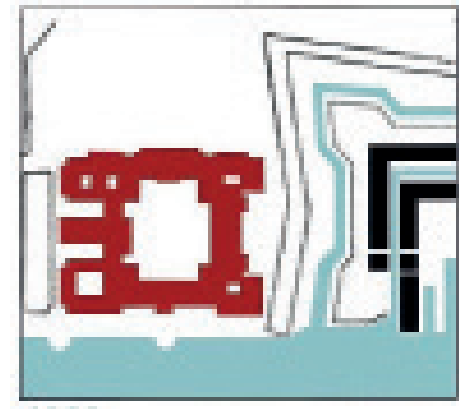

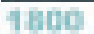

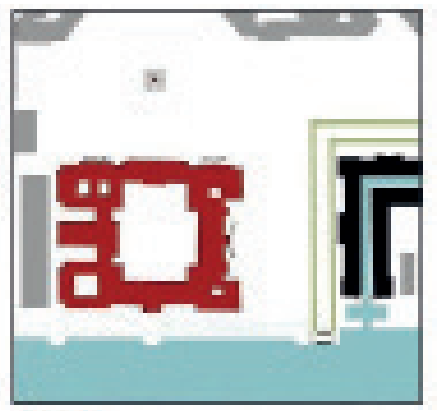

41879

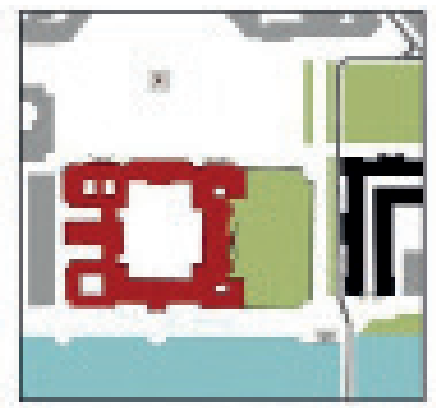

1910

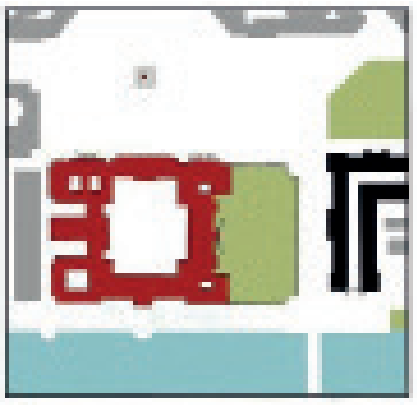

20140

Pис. 9. Основные этапы развития части городского центра между Адмиралтейством и Зимним дворцом 


\section{Лuтература}

1. Адмиралтейство [Электронный ресурс] // Информационно-образовательный портал «Знания». - Режим доступа: https://znanija.com/task/3197604 (дата обращения 26.04.2018).

2. Гомзин Иван Григорьевич [Электронный ресурс] // Информационный портал «Словари, энциклопедии, справочники» - Slovar.cс. - Режим доступа: https://slovar.cc/ist/ biografiya/2256842 (дата обращения 26.04.2018).

3. Адмиралтейство: факты из истории создания [Электронный ресурс] // Портал «Культура.рф». - Режим доступа: https://www.culture.ru/materials/129726/admiralteistvo (дата обращения 11.05.2018).

4. Ляшко, E. Вода на суше. Как менялось здание Адмиралтейства в Петербурге [Электронный ресурс] // Информационный портал «Аргументы и факты». - Режим доступа: http:// www.spb.aif.ru/city/event/voda_na_sushe_kak_menyalos_ so_vremenem_zdanie_admiralteystva_v_peterburge (дата обращения 26.04.2018).

5. Адмиралтейство [Электронный ресурс] // Информационный портал «іPetersburg». - Режим доступа: http:// www.ipetersburg.ru/admiralteystvo11/ (дата обращения 26.04.2018).

6. Семенцов, С.В. Этапы формирования пространственной среды Санкт-Петербурга. Ч. 1. Историческое развитие кварталов и их регламентация / С.В. Семенцов // Вестник гражданских инженеров. - 2006. - № 2 (7). - С. 15-20.

7. Адмиралтейство [Электронный ресурс] // Приветъ Питеръ. - Режим доступа: http://www.hellopiter.ru/Admiralty. html (дата обращения 12.05.2018).

8. Санкт-Петербург на картах и планах первой половины XVIII века / С.В. Семенцов, О.А. Красникова, Т.П. Мазур, Т.А. Шрадер. - СПб: Эклектика, 2004. - 436 с.

9. Батюшков, К.Н. Прогулка в Академию художеств: Письмо старого московского жителя к приятелю, в деревню его Н. / К.Н. Батюшков // Батюшков К.Н. Опыты в стихах и прозе / АН СССР; Изд. подгот. И.М. Семенко. - М.: Наука, 1977. - (Лит. памятники). - С. 71-94.

10. Рисунки Кваренги - Санкт-Петербург [Электронный ресурс] // Livejournal. - Режим доступа: https://kraeveds-spb. livejournal.com/203586.html\#/203586.html (дата обращения 12.05.2018).

11. Новое Адмиралтейство [Электронный ресурс] // Архитектурный сайт Санкт-Петербурга «Citywalls». - Режим доступа: http://www.citywalls.ru/house8261.html (дата обращения 01.05.2018).

12. Королёв, К.М. Санкт-Петербург. Автобиография [Электронный ресурс] // ВикиЧтение. - Режим доступа: https://history.wikireading.ru/287500 (дата обращения 01.05.2018).

13. Тимофеев, А.Т. История С.-Петербургской биржи. СПб., 1903. - С.78-79 /цит.по Басаргина Е.Ю., Щедрова И.М.
Развитие академического ансамбля на стрелке Васильевского острова во второй половине XVIII - первой трети XIX века. [Электронный ресурс] // Санкт-Петербургский филиал архива Российской академии наук. - Режим доступа: http:// www.ranar.spb.ru/rus/books6/id/592/ (дата обращения: 01.02.2016).

14. Здание Адмиралтейства. Грав. с карты Петербурга 1820-1825 [Электронный ресурс] // Архитектурный сайт Санкт-Петербурга «Citywall». - Режим доступа: http:// p0.citywalls.ru/photo_181-186304.jpg?mt=1391807330 (дата обращения 12.05.2018).

15. Санкт-Петербург. Ростральные колонны [Электронный ресурс] // Интернет-журнал «Travelask». - Режим доступа: http://travelask.ru/russia/saint-petersburg/sankt-peterburgrostralnye-kolonny (дата обращения 12.05.2018)

16. Лисовский, В.Г. Архитектура Петербурга. Три века истории / В.Г. Лисовский. - СПб: АО «Славия», 2004. - 416 с.

17. Сашонко, В.Н. Адмиралтейство / В.Н. Сашонко. - Л.: Лениздат, 1982. - 126 с.

18. Шуйский, В.К. Андреян Захаров / В.К. Шуйский. - Л.: Лениздат, 1989. - 190 с.

19. Адмиралтейская набережная. [Электронный ресурс] // Википедия. - Режим доступа: https://upload.wikimedia.org/ wikipedia/commons/c/c1/Admiralty_Embankment_-_1881.jpg (дата обращения 12.05.2018).

20. Фотоальбом к 25-летию 000 «ВИБРОТЕХНИК»: «СанктПетербург с высоты птичьего полёта». Фотограф Д. Песочинский. [Электронный ресурс] // Вибротехник. - Режим доступа: http://vt-spb.ru/news/novogodniy-fotoalbom-2017. php (дата обращения 12.05.2018).

21. Kuenstliche Welten - Retortenstaedte mitten im nirgendwo. [Электронный ресурс] // Welderwunder. - Peжим доступа: http://www.weltderwunder.de/photo_stories/ kuenstliche-welten-retortenstaedte-mitten-im-nirgend wo (дата обращения 26.04.2018).

22. Курбатов, В.Я. Петербург: Художественно-исторический очерк и обзор художественного богатства столицы / Сост. В. Курбатов; Книж. украшения А.П. Остроумовой-Лебедевой. - СПб.: Община св. Евгении, 1913 (Товарищество Р. Голике и А. Вильборг). - 674 с.: ил. - С. 315.

23. Грабарь, И.Э. История русского искусства. Том III. Архитектура / И.Э. Грабарь. - М.: Издание И. Кнебель, 1910. -599 c.

24. Рославлев, М. Старый Петербург - Новый Ленинград / М. Рославлев. - Л.: Изд. Академии художеств, 1928. - 132 с.

25. Historic Centre of Saint Petersburg and Related Groups of Monuments. [Электронный ресурс] // UNESCO. - Режим доступа: http://whc.unesco.org/en/list/540 (дата обращения 22.05.2018).

26. Александровский сад. [Электронный ресурс] Прогулки по Петербургу. - Режим доступа: https://walkspb.ru/sad/ aleksandr_sad.html (дата обращения: 06.07.2016). 


\section{Literatura}

1. Admiraltejstvo [Elektronnyj resurs] // Informatsionnoobrazovatel'nyj portal «Znaniya». - Rezhim dostupa: https:// znanija.com/task/3197604 (data obrashheniya 26.04.2018).

2. Gomzin Ivan Grigor'evich [Elektronnyj resurs] // Informatsionnyj portal «Slovari, entsiklopedii, spravochniki» - Slovar.cc. - Rezhim dostupa: https://slovar.cc/ist/ biografiya/2256842 (data obrashheniya 26.04.2018).

3. Admiraltejstvo: fakty iz istorii sozdaniya [Elektronnyj resurs] // Portal «Kul'tura.rf». - Rezhim dostupa: https://www. culture.ru/materials/129726/admiralteistvo (data obrashheniya 11.05.2018).

4. Lyashko E. Voda na sushe. Kak menyalos' zdanie Admiraltejstva $\vee$ Peterburge [Elektronnyj resurs] // Informatsionnyj portal «Argumenty i fakty». - Rezhim dostupa: http://www.spb.aif.ru/city/event/voda_na_sushe_kak_ menyalos_so_vremenem_zdanie_admiralteystva_v_peterburge (data obrashheniya 26.04.2018).

5. Admiraltejstvo [Elektronnyj resurs] // Informatsionnyj portal «iPetersburg». - Rezhim dostupa: http://www. ipetersburg.ru/admiralteystvo11/ (data obrashheniya 26.04.2018).

6. Sementsov S.V. Etapy formirovaniya prostranstvennoj sredy Sankt-Peterburga. Ch. 1. Istoricheskoe razvitie kvartalov $\mathrm{i}$ ih reglamentatsiya / S.V. Sementsov // Vestnik grazhdanskih inzhenerov. - 2006. -№ 2 (7). - S. 15-20.

7. Admiraltejstvo [Elektronnyj resurs] // Privet "Piter". - Rezhim dostupa: http://www.hellopiter.ru/Admiralty.html (data obrashheniya 12.05.2018).

8. Sankt-Peterburg na kartah i planah pervoj poloviny XVIII veka / S.V. Sementsov, 0.A. Krasnikova, T.P. Mazur, T.A. Shrader. - SPb: Eklektika, 2004. - 436 s.

9. Batyushkov K.N. Progulka v Akademiyu hudozhestv: Pis'mo starogo moskovskogo zhitelya $\mathrm{k}$ priyatelyu, $v$ derevnyu ego $\mathrm{N}$. / K.N. Batyushkov // Batyushkov K.N. Opyty v stihah i proze / AN SSSR; Izd. podgot. I.M. Semenko. - M.: Nauka, 1977. - (Lit. pamyatniki). - S. 71-94.

10 Risunki Kvarengi - Sankt-Peterburg [Elektronnyj resurs] // Livejournal. - Rezhim dostupa: https://kraevedsspb.livejournal.com/203586.html\#/203586.html (data obrashheniya 12.05.2018).

11. Novoe Admiraltejstvo [Elektronnyj resurs]// Arhitekturnyj sajt Sankt-Peterburga «Citywalls». - Rezhim dostupa: http://www.citywalls.ru/house8261.html (data obrashheniya 01.05.2018).

12. Korolev K.M. Sankt-Peterburg. Avtobiografiya [Elektronnyj resurs] // VikiChtenie. - Rezhim dostupa: https://history.wikireading.ru/287500 (data obrashheniya 01.05.2018).

13. Timofeev A.T. Istoriya S.-Peterburgskoj birzhi. - SPb., 1903. - S.78-79 / tsit.po Basargina E.Yu., Shhedrova I.M. Razvitie akademicheskogo ansamblya na strelke Vasil'evskogo ostrova vo vtoroj polovine XVIII - pervoj treti XIX veka. [Elektronnyj resurs] // Sankt-Peterburgskij filial arhiva Rossijskoj akademii nauk. - Rezhim dostupa: http://www. ranar.spb.ru/rus/books6/id/592/ (data obrashheniya: 01.02.2016).

14. Zdanie Admiraltejstva. Grav. s karty Peterburga 1820-1825 [Elektronnyj resurs] // Arhitekturnyj sajt SanktPeterburga «Citywall». - Rezhim dostupa: http://p0.citywalls. ru/photo_181-186304.jpg?mt=1391807330 (data obrashheniya 12.05.2018).

15. Sankt-Peterburg. Rostral'nye kolonny [Elektronnyj resurs] // Internet-zhurnal «Travelask». - Rezhim dostupa: http://travelask.ru/russia/saint-petersburg/sankt-peterburgrostralnye-kolonny (data obrashheniya 12.05.2018).

16. Lisovskij V.G. Arhitektura Peterburga. Tri veka istorii / V.G. Lisovskij. - SPb: A0 «Slaviya», 2004. - 416 s.

17. Sashonko V.N. Admiraltejstvo / V.N. Sashonko. - L.: Lenizdat, 1982. - $126 \mathrm{~s}$.

18. Shujskij V.K. Andreyan Zaharov / V.K. Shujskij. - L.: Lenizdat, 1989. - $190 \mathrm{~s}$.

19. Admiraltejskaya naberezhnaya. [Elektronnyj resurs] // Vikipediya. - Rezhim dostupa: https://upload.wikimedia.org/ wikipedia/commons/c/c1/Admiralty_Embankment_-_1881.jpg (data obrashheniya 12.05.2018).

20. Fotoal'bom k 25-letiyu 000 «VIBROTEHNIK»: «SanktPeterburg s vysoty ptich'ego poleta». Fotograf D. Pesochinskij. [Elektronnyj resurs] // Vibrotehnik. - Rezhim dostupa: http://vt-spb.ru/news/novogodniy-fotoalbom-2017.php (data obrashheniya 12.05.2018).

21. Kuenstliche Welten - Retortenstaedte mitten im nirgendwo. [Elektronnyj resurs] // Welderwunder. - Rezhim dostupa: http://www.weltderwunder.de/photo_stories/ kuenstliche-welten-retortenstaedte-mitten-im-nirgendwo (data obrashheniya 26.04.2018).

22. Kurbatov V.Ya. Peterburg: Hudozhestvenno-istoricheskij ocherk i obzor hudozhestvennogo bogatstva stolitsy / Sost. V. Kurbatov; Knizh. ukrasheniya A.P. Ostroumovoj-Lebedevoj. SPb.: Obshhina sv. Evgenii, 1913 (Tovarishhestvo R. Golike i A. Vil'borg). - 674 s.: il. - S. 315.

23. Grabar' I.E. Istoriya russkogo iskusstva. Tom III. Arhitektura / I.E. Grabar'. - M.: Izdanie I. Knebel', 1910. - 599 s.

24. Roslavlev M. Staryj Peterburg - Novyj Leningrad / M. Roslavlev. - L.: Izd. Akademii hudozhestv, 1928. - 132 s.

25. Historic Centre of Saint Petersburg and Related Groups of Monuments. [Elektronnyj resurs] // UNESCO. - Rezhim dostupa: http://whc.unesco.org/en/list/540 (data obrashheniya 22.05.2018).

26. Aleksandrovskij sad. [Elektronnyj resurs] Progulki po Peterburgu. - Rezhim dostupa: https://walkspb.ru/sad/ aleksandr_sad.html (data obrashheniya: 06.07.2016). 
Лавров Леонид Павлович, 1939 г.р. (Санкт-Петербург). Доктор архитектуры, профессор, член-корреспондент РААСН, членкорреспондент Германской академии градостроительства и планирования земель. Профессор-консультант СПБГАСУ (190005, Россия, Санкт-Петербург, 2-я Красноармейская ул., 4. СПбГАСУ). Область научных интересов - жилая среда крупнейшего города. Автор около 250 публикаций. Тел.: 8 (812) 575-05-10. E-mail:leonid.lavrov@gmail.com.

Перов Федор Викторович, 1956 г.р. (Санкт-Петербург). Кандидат архитектуры, доцент. Декан архитектурного факультета СПбГАСУ (190005, Россия, Санкт-Петербург, 2-я Красноармейская ул., 4. СПбГАСУ). Область научных интересов - архитектура жилых и общественных зданий. Автор более 60 публикаций. Тел.: 8 (812) 575-05-10. E-mail: f.perov@gmail.com.

Еремеева Александра Федоровна, 1989 г.р. (Санкт-Петербург). Кандидат архитектуры. Доцент кафедры дизайна архитектурной среды СПбГАСУ (190005, Россия, Санкт-Петербург, 2-я Красноармейская ул., 4. СПбГАСУ). Область научных интересов - архитектура жилых и общественных зданий, городская среда. Автор более 30 публикаций. Тел.: 8 (931) 224-21-34. E-mail: arch.eremeeva@gmail.com.

Lavrov Leonid Pavlovich, born in 1939. (St. Petersburg). Doctor of architecture, professor, corresponding member of the RAACS, corresponding member of the German Academy of Urban and Land Use Planning (DASL). Professor-consultant of the Saint Petersburg State University of Architecture and Civil Engineering (190005, Russia, St. Petersburg, 2nd Krasnoarmeyskaya st., 4. SPSUACE). Sphere of scientific interests: residential environment of thelargest city. Author of about 250 publications. Tel.: +7 (812) 575-05-10. E-mail:leonid.lavrov@gmail.com.

Perov Fedor Viktorovich, born in 1956 (St. Petersburg). Candidate of Architecture. Docent Dean of the Faculty of Architecture of Petersburg State University of Architecture and Civil Engineering (190005, Russia, St. Petersburg, 2nd Krasnoarmeyskaya str., 4. SPSUACE). Research interests: architecture of residential and public buildings. Author of more than 60 publications. Tel: 8 (812) 575-05-10. E-mail: f.perov@gmail.com.

Eremeeva Aleksandra Fedorovna, born in 1989 (St. Petersburg). Candidate of Architecture, Associate Professor, Chair of Design of Architectural Environment of Petersburg State University of Architecture and Civil Engineering (190005, Russia, St. Petersburg, 2nd Krasnoarmeyskaya str., 4. SPSUACE). Research interests: architecture of residential and public buildings, urban environment. Author of more than 30 publications. Tel: 8 (931) 224-21-34. E-mail: arch.eremeeva@gmail.com. 